\title{
Transfusion Reactions
}

\author{
Jürgen Bux \\ DRK-Blutspendedienst West, Hagen, Germany
}

With the occurrence of HIV in human blood donors in the 1980s, transfusion-transmitted viral infections and their prevention became a central issue for blood services. Today, the transmission of HIV as well as hepatitis B and C is extremely rare, even more rare than the likelihood of being struck by lightning. In consequence, the classical transfusion reactions are brought into focus again. Thanks to the comprehensive data of the British 'Serious Hazards of Transfusion' (SHOT) initiative which has reported its findings since 1996, transfusion reactions have been recalled as the important causes for transfusion-associated major morbidity and death. Therefore, in this issue of Transfusion MEdicine And Hemotherapy, a section about selected transfusion reactions is included.

One article deals with pulmonary transfusion reactions among them the long neglected transfusion-related acute lung injury (TRALI) [1]. The SHOT reports showed that TRALI is currently the major cause of transfusion-associated death. This was confirmed by the reports of the US Food and Drug Administration which are in line with preliminary data of the Paul Ehrlich Institute. The hemovigilance data indicate that underreporting, misdiagnosis, and misclassification have prohibited the recognition of the clinical importance of TRALI.
Preventive measures are currently a matter of debate. Hemolytic transfusion reactions, which are still another important cause of transfusion-associated major morbidity and death, are discussed in second review [2]. A third review deals with the transfusion of platelets which is frequently associated with adverse events [3]. Finally, as there is a renewed discussion about the adverse effects of transfusion of stored red blood cells, this is subject of the last review in this special section about transfusion reactions [4].

Hopefully, these reviews will contribute to a better understanding of these transfusion reactions, resulting in a further improvement of preventive measures.

\section{References}

Bux J, Sachs UJH: Pulmonary transfusion reactions. Transfus Med Hemother 2008:35(5):337-345.

2 Strobel E: Hemolytic transfusion reactions. Transfus Med Hemother 2008;35 (5):346-353.

3 Kiefel V: Reactions induced by platelet transfusions. Transfus Med Hemother 2008;35(5):354-358.

4 Van de Watering LMG, Brand A: Adverse transfusion effects of red cell storage. Transfus Med Hemother 2008;35(5):359-367.

\begin{tabular}{ll}
\hline KARGER & ๑ 2008 S. Karger GmbH, Freiburg \\
Fax +497614520714 & Accessible online at: \\
$\begin{array}{l}\text { Information@Karger.de } \\
\text { www.karger.com }\end{array}$ & www.karger.com/tmh
\end{tabular}

